\title{
小規模木質系バイオマス CGS STUDY ON EFFECT OF SMALL SCALE の導入効果に関する研究 WOODEN BIOMASS CO-GENERATION SYSTEM
}

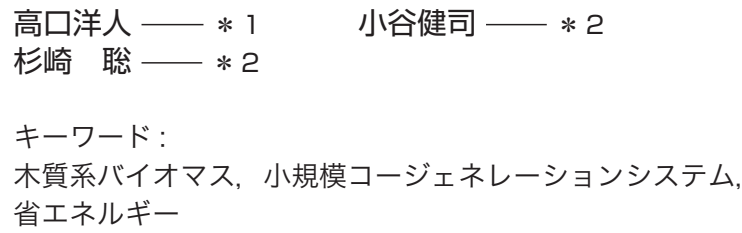

Keywords:

Wooden biomass, Small scale Co-Generation System, Energy saving

\author{
Hiroto TAKAGUCHI — $* 1$ \\ Satoshi SUGISAKI — $* 2$ \\ Kenji KOTANI -2
}

This paper reports the results of small scale wooden biomass CoGeneration System (we call it WBCGS) that had been introduced into S Prefecture T city in 2007. WBCGS uses LPG to start the gas engine and produce heat and electricity sent to the demand side. The fuel of the engine is a wood chip. The raw material of the wood chip is local thinned wood, forest reminder material, and mill ends.

As the result of the yearly total efficiency was $62.9 \%$, the power generation efficiency was $10.6 \%$, and thermal efficiency was $52.3 \%$. After WBCGS had been introduced, $101 \mathrm{t}-\mathrm{CO}_{2}$ a year was reduced $88.6 \%$ has been reduced compared with conventional system.

\section{1. はじめに}

発展途上国での石油消費が急増している中、すでにオイルピーク は過ぎたとも言われており、脱化石燃料社会の構築が強く求められ ている。そのためにはあらゆる局面で再生可能エネルギーを供給す ることが必要である ${ }^{1)}$ 。なかでも、特に間伐材などの森林資源を活 用した木質系バイオマスを原料とした熱利用や発電は、森林再生や 地場産業の振興、カーボンニュートラルの立場からも注目され、低 炭素循環型社会を構築するうえで、今後さらに増加すると考えられ ている。NEDO が発表している文献 ${ }^{23)}$ によると現在国内において木 質系バイオマスでガス化発電を行っている施設は 8 箇所で試験運転 や運転中止の施設を除外すると 5 箇所ほどしか存在しない。今後、 木質バイオマス CGS(以下 WBCGS)の普及を進めるかどうかはこれら 既存の施設の運転実績や導入効果を検証することは重要である。

そこで本報では $\mathrm{S}$ 県 $\mathrm{T}$ 市に平成 19 年に導入された小規模木質系バ イオマス CGS (以下 WBCGS)の平成 19 年度実績を解析し、その導入効 果について検証する。

\section{2. 導入システム}

\section{1 供給対象施設の概要}

表 1 に供給対象施設の施設概要、図 1、図 2 に WBCGS のガス化炉 とガスエンジンを示す。WBCGS は宿泊施設であるコテージや食堂、 クラブハウスなどの有する市営のリクリエーション施設に導入され ている。発電した電気は所内で消費されており一部売電を行ってい る。発生した熱は風呂、足湯の熱源として使用されている。このリ クリエーション施設には WBCGS のほかに、入浴施設やトイレからの 排水を処理するための排水処理施設、太陽光発電システム、市内の 学校給食や家庭の使用済みてんぷら油をリサイクルしてバイオディ 一ゼル燃料を製造する工場がある。この施設は小・中学生の環境学 習プログラムとしても活用されている。平成 20 年 3 月には発電所の

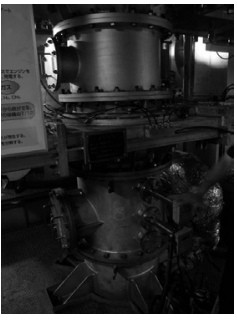

図 1 ガス化炉

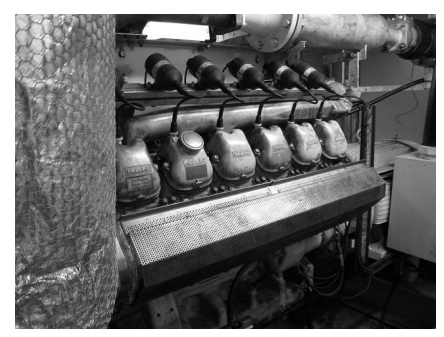

図 2 ガスエンジン
表 1 供給対象施設の施設概要

\begin{tabular}{|c|c|c|c|c|c|c|}
\hline \multirow[b]{2}{*}{ No, } & \multirow[b]{2}{*}{ 名称 } & \multirow[b]{2}{*}{ 階数 } & \multirow{2}{*}{ 延べ床面積 } & \multirow[b]{2}{*}{ 用途 } & \multicolumn{2}{|r|}{ 冷暖房設備 } \\
\hline & & & & & 使用エネルギー & 設置場所 \\
\hline \multirow[b]{2}{*}{1} & \multirow{2}{*}{ クラブハウス } & \multirow[b]{2}{*}{2} & \multirow{2}{*}{$1,300 \mathrm{~m}^{2}$} & 事務所、食堂 & 電気 & 1 階、2階和室、休憼所など \\
\hline & & & & 党店浴室 & LPG & 食堂、屜房、玄関ホールなど \\
\hline 2 & コテージ (6人用) & 2 & $50 \mathrm{~m}^{2} \times 5$ 棟 & 宿泊施設 & \multicolumn{2}{|c|}{ LPG (椧房)、電気 (暖房) } \\
\hline 3 & コテージ $(9$ 人用 $)$ & 2 & $70 \mathrm{~m}^{2} \times 6$ 棟 & 宿泊施設 & \multicolumn{2}{|c|}{ LPG (冷房)、電気 (暖房) } \\
\hline 4 & 発電所 & 7 & $180 \mathrm{~m}^{2}$ & 発電所 & & \\
\hline 5 & 体育館 & 1 & $1,000 \mathrm{~m}^{2}$ & 体育施設 & & \\
\hline \multicolumn{3}{|c|}{ 小計 } & $3,150 \mathrm{~m}^{2}$ & & & \\
\hline
\end{tabular}

表 2 WBCGS の設計値

\begin{tabular}{|c|c|c|}
\hline 方式 & \multicolumn{2}{|c|}{ 木材チップを燃料とするガスエンジンCGS } \\
\hline \multirow{5}{*}{$\begin{array}{c}\text { 仕様 } \\
\text { (設計値) }\end{array}$} & 発電端出力 & 115kW(発電効率 23\%) \\
\hline & 送電端出力 & $100 \mathrm{~kW}$ \\
\hline & 総回収熱量 & 966MJ/h (回収効率50\%) \\
\hline & 有効利用熱量 & $629 \mathrm{MJ} / \mathrm{h}$ \\
\hline & 木質バイオマス使用量 & $125 \mathrm{~kg} / \mathrm{h}, 1.5 \mathrm{t} /$ 日 \\
\hline 想定運転時間 & \multicolumn{2}{|c|}{12 時間/日，300日/年 } \\
\hline
\end{tabular}

排熱を利用したクロレラ栽培所も建設されている。尚これらは WBCGS の供給対象先には含まれない。

\section{2 木質系バイオマス CGS}

表 2 にWBCGS の設計值を示す。供給対象施設の営業時間に合わせ、 1 日約 12 時間、年間約 300 日運転するものと想定され、電気と温水 を供給する。設計值での発電効率は $23 \%$ 、熱回収効率は $50 \%$ ある。 また燃料となる木材チップは $450 t /$ 年 (1.5t/日) 使用することを想

\footnotetext{
早稲田大学理工学術院 准教授・博士 (工学)

（干 169-8555 東京都新宿区大久保 3-4-1 55N705)

早稲田大学創造理工学研究科 修士課程
}

\footnotetext{
Assoc. Prof., Faculty of Science and Engineering, Waseda Univ., Dr. Eng.

*2 Graduate Student, School of Creative Science and Engineering, Waseda Univ.
} 
定しており、その原料は地場産の間伐材、森林残材、製材所の端材 などから成り立っている。

\section{3 導入システム}

図 3 に WBCGS システム図を示す。木材チップはストックヤードか らクレーンにより乾燥機に運ばれる。乾燥機でほぼ絶乾に近い状態 にしてガス化炉に投入される。ガス化炉にて約 1100 度でチップのガ ス化を行う。この可然性のガスを利用してガスエンジンを回して発 電、排熱を回収し埋設配管を通じて供給対象施設へ送られる。電気 は各施設に送られる。温水は熱交換を行い、一度貯湯槽へ送られた 後、施設内の風呂や足湯に供給されている。それ以外の利用方法と して温水を熱交換し、木材乾燥機用の温風として使われている。電 気は施設内消費がほとんどであるが、一部売電も行っている。夜間 は電力消費量が少ないので運転を停止をし、電力会社から購入して いる。

\section{3. 運転状況}

\section{1 一日の運転状況}

図 4 に平成 19 年 4 月 1 日の運転状況 (INPUT)、LPG と木材チップ 燃焼量を示す。図 5 に平成 19 年 4 月 1 日の運転状況 (OUTPUT)、発 電量と回収熱量と WBCGS の総合効率を示す。なおここでの総合効率 は 1 式と定義している。

$$
E_{T}=\frac{E_{G}+H_{W}+E_{H}}{W_{B}+L_{P}} \times 100 \quad \cdots \cdots 1 \text { 式 }
$$

$E_{T}$ : 総合効率 $(\%) \quad W_{B}^{* 1}$ : 木材燃焼量 $(\mathrm{MJ}) \quad L_{P}: \mathrm{LPG}$ 使用量 $(\mathrm{MJ})$

$E_{G}$ : 発電量 $(\mathrm{MJ}) \quad H_{W}$ : 温水供給量 (有効利用熱量) $(\mathrm{MJ})$

$E_{H}:$ 排熱 (木材乾燥機用) $(\mathrm{MJ})$

この日は 10 時にLPG を使用しガスエンジンを起動させ運転を開始 する。20 時にエンジンは停止させていているため電気と排熱は回収 されないが、ガスエンジンに溜まったタールを燃焼させるために 22 時に LPG を使用する。また温水は $11^{\circ} \mathrm{C}$ の市水を $80^{\circ} \mathrm{C}$ 加熱して供給 している。1 日で木材チップ約 $1232 \mathrm{~kg}$ を 48 回に分けて使用してい る。終日の総合効率は $74.2 \%$ 、発電効率は $12.7 \%$ 、有効利用熱量と排 熱を合わせた総熱回収効率は $61.5 \%$ ある。この日最も効率がよか ったのは 11 時〜 12 時の 1 時間で総合効率は $92 \%$ 、発電効率は $23 \%$ 、 熱回収効率は $69 \%$ である。起動時は LPG を余熱用として使用するた め総合効率は低くなる。起動して 1 時間後は LPG の使用による熱が 残っているためか最も効率が良くなる。

\section{2 各季節での運転状況}

\section{2.1 中間季の運転状況}

図 6 に中間季(平成 19 年 4 月 1 日〜 月 30 日)の運転状況を示す。 総合効率は $67.8 \%$ 、発電効率は $12.5 \%$ 、熱回収効率は $55.3 \%$ あった。 稼㗢日数は 24 日間で、月間積算発電量は $72,954 \mathrm{MJ}$ で月間積算 回収熱量は 326, 957MJ であった。 4 月 6 日、 4 月 9 日の 2 日間は発電 量が非常に低い。この理由は両日とも管理上の問題から 2 時間ほど の夜間運転のみしか行えなかったことが原因である

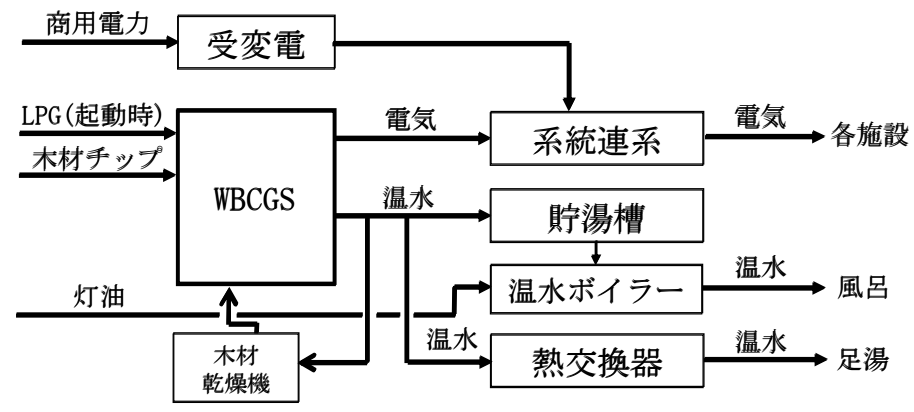

図 3 WBCGS システム図

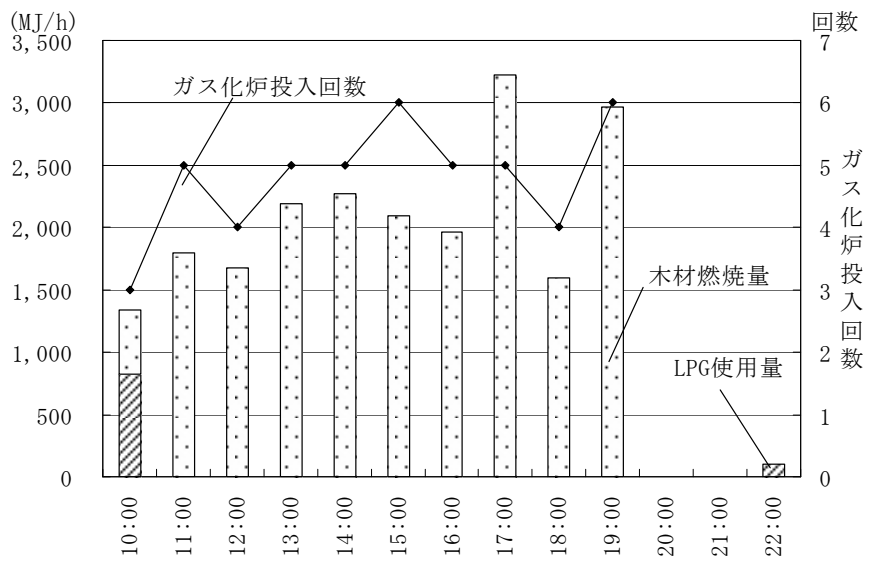

図 4 平成 19 年度 4 月 1 日の運転状況 (INPUT)

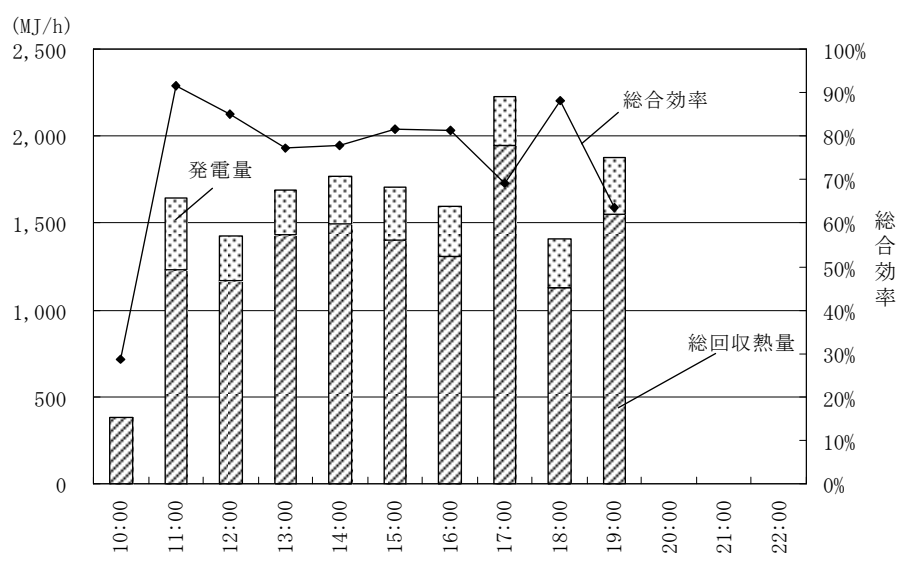

図 5 平成 19 年度 4 月 1 日の運転状況 (OUTPUT)

\section{2.2 夏季の発電状況}

図 7 に夏季(平成 19 年 8 月 2 日〜 8 月 31 日)の運転状況を示す。 総合効率は $61.1 \%$ 、発電効率は $11.0 \%$ 、熱回収効率は $50.1 \%$ あった。 稼働日数は 26 日間で月間積算発電量は $61,916 \mathrm{MJ}$ で月間積算回収熱 量は 283,478MJ であった。 8 月 2 日、3 日、5 日、21 日、26 日は稼 働時間が短いため発電量、回収熱量ともに低い。

\section{2.3 冬季の発電状況}

図 8 に冬季(平成 19 年 1 月 3 日〜 月 29 日)の運転状況を示す。 月間総合効率は $63.4 \%$ 、発電効率は $10.6 \%$ 、熱回収効率は $52.8 \%$ あ った。稼働日数は 24 日間で月間積算発電量 $621,22 \mathrm{MJ}$ で月間積算回 収熱量は $311,240 \mathrm{MJ}$ であった。1月 18 日は稼働時間が短いため発電 量、回収熱量ともに低い。 


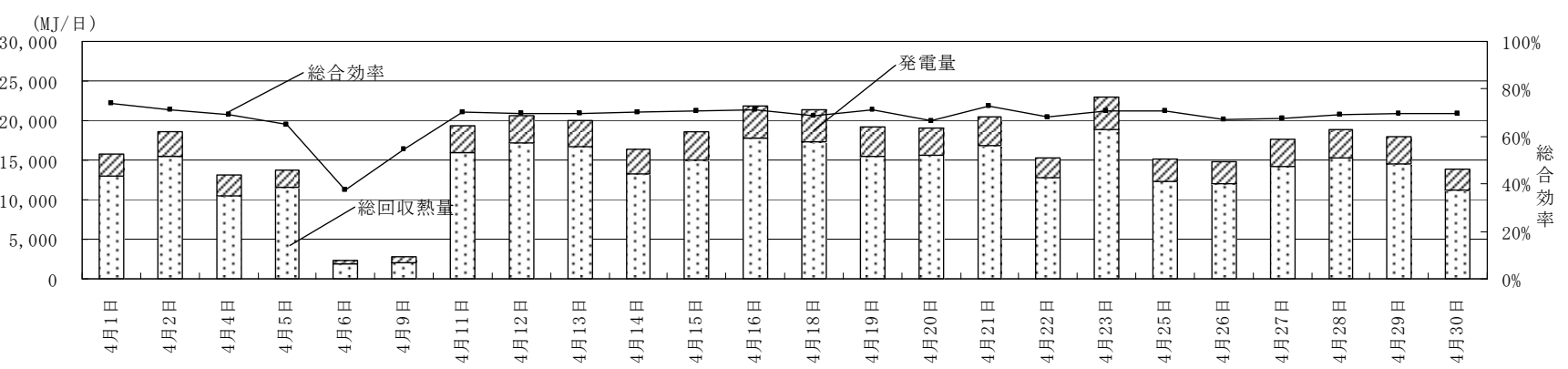

図 6 中間季 (平成 19 年 4 月 1 日 4 月 30 日) 運転状況

$(\mathrm{MJ} /$ /日)

25,000

20,000

15,000

10, 000

5,000

0

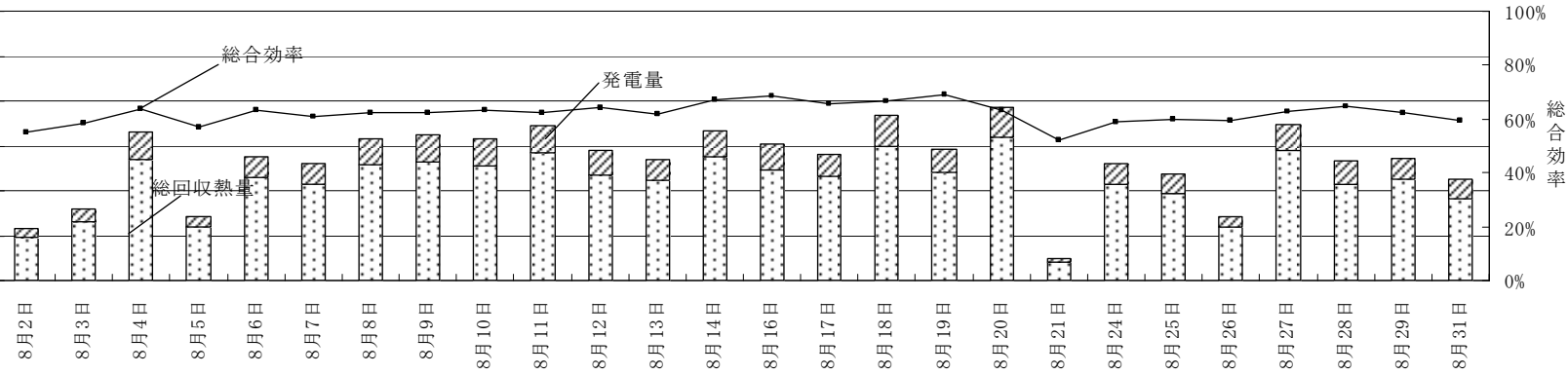

図 7 夏季 (平成 19 年 8 月 2 日 8 月 31 日) 運転状況

(MJ/日)

20,000

15,000

10,000

5, 000

0

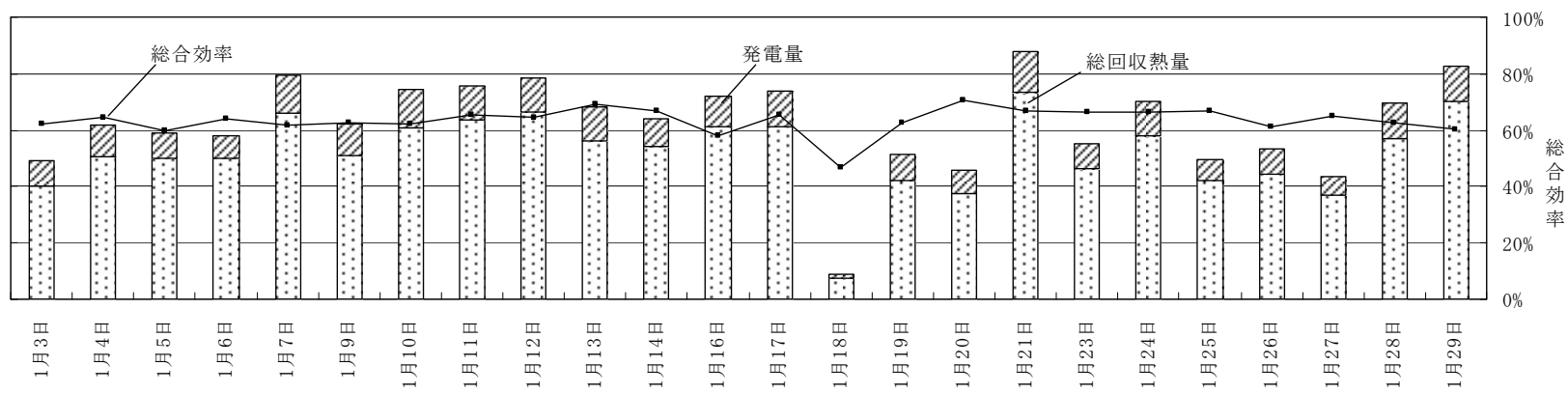

図 8 冬季(平成 19 年 1 月 3 日 1 月 29 日) 運転状況

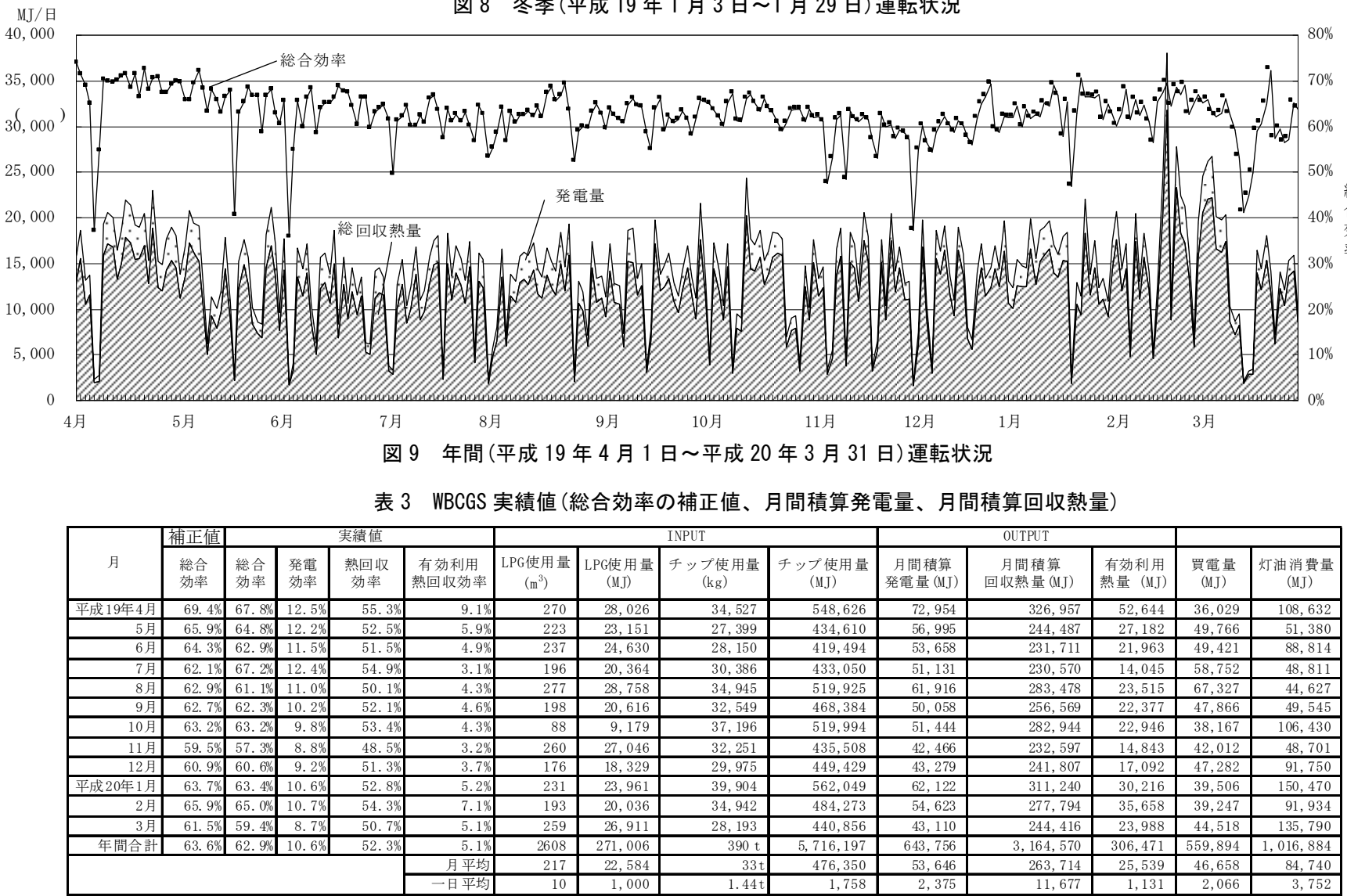




\section{3 年間運転状況}

図 9 に平成 19 年の年間 (平成 19 年 4 月 1 日〜平成 20 年 3 月 31 日)運転状況を示す。年間運転日数は 271 日で年間総合効率は $62.9 \%$ 、 発電効率は $10.6 \%$ 、熱回収効率は $52.3 \%$ でった。設計值と比べて発 電効率は低く、熱回収効率は高くなる結果となった。

\section{4 WBCGS 実績値}

表 3 に WBCGS の実績值 (総合効率の補正值、月間積算発電量、月間 積算回収熱量など)を示す。図 10 で総合効率が著しく低い日がある が、この原因は供給対象施設の管理上の問題で運転時間が確保でき なかったり、月ごとに木材チップの形状を変えていたりしているか らである。そのため、その日を除外した総合効率の補正值を算出し た。補正值では年間総合効率は $63.6 \%$ となった。また回収熱量のう ちの風呂や足湯に利用された割合、有効利用熱回収効率は $5.1 \%$ と なっており、熱は木材乾燥機での乾燥用温風に使われる割合が高い ことがわかった。

\section{5 年間エネルギー消費量と発電量、発生熱量の関係}

図 10 に供給対象施設の月ごとのエネルギー消費量と WBCGS の生成 エネルギーの関係を示す。正の数はチップ燃焼量、灯油消費量、 LPG 消費量、電力消費量は供給対象施設でのエネルギー消費量で、負の 数はWBCGSによって生成された有効利用熱量、発電量で供給対象施 設にて利用されたエネルギー量である。供給対象施設が年間消費エ ネルギーは、 $8,374 \mathrm{GJ} /$ 年で WBCGS による有効利用熱量、発電量は、 $678 \mathrm{GJ} /$ 年であった。これは全体の $8.1 \%$ を占めている。

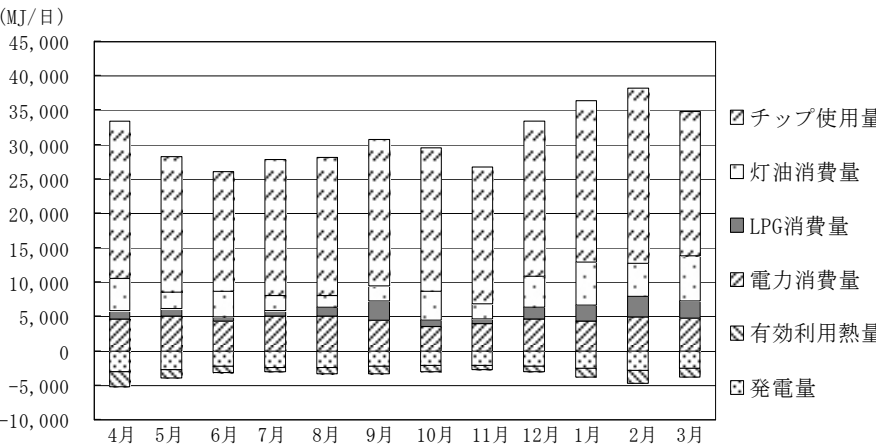

図 10 エネルギー消費量と利用エネルギーの関係

\section{WBCGS システム導入効果}

\section{$4.1 \mathrm{CO}_{2}$ 削減効果算出方法}

図 11 に従来システム図を示す。従来システムでは WBCGS で生成さ れた電気と風呂、足湯の熱源に利用された熱量を商用電力と LPG ボ イラーで賄うものとし、WBCGS を稼働する際に発生する $\mathrm{CO}_{2}$ 排出量と 比較を行った。表 4、表 5、従来システム、現状の $\mathrm{CO}_{2}$ 換算表を示す。 木質チップの燃焼による $\mathrm{CO}_{2}$ 排出量は、カーボンニュートラルの観 点から算入していない。

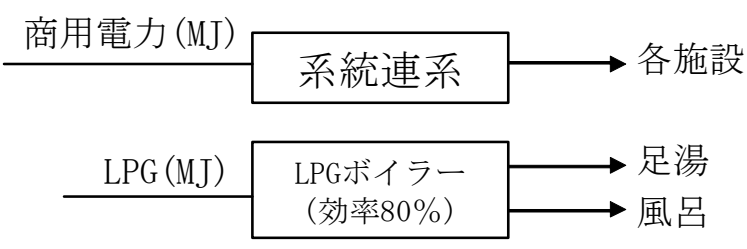

図 11 従来システム図
表 4 比較システム $\mathrm{CO}_{2}$ 換算表 ${ }^{5}$

\begin{tabular}{c|r|r|r|c}
\hline & $\mathrm{MJ}$ & $\begin{array}{r}\text { 排出原単位 } \\
\left(\mathrm{kg}-\mathrm{CO}_{2} / \mathrm{MJ}\right)\end{array}$ & $\begin{array}{c}\mathrm{CO}_{2} \text { 排出量 } \\
\left(\mathrm{kg}-\mathrm{CO}_{2}\right)\end{array}$ & $\begin{array}{c}\text { 合計 } \\
\left(\mathrm{kg}-\mathrm{CO}_{2}\right)\end{array}$ \\
\hline 買電 & 559,894 & 0.1540 & 86,224 & \multirow{2}{*}{124,750} \\
\cline { 1 - 4 } $\mathrm{LPG}$ 使用量 & 787,856 & 0.0489 & 38,526 & \multirow{2}{*}{ チップ熱量 } \\
\cline { 1 - 4 } & 0 & 0 & 0 & \\
\hline
\end{tabular}

表 5 現状 $\mathrm{CO}_{2}$ 換算表 ${ }^{5)}$

\begin{tabular}{l|c|r|r|c}
\hline & $\mathrm{MJ}$ & $\begin{array}{r}\text { 排出原単位 } \\
\left(\mathrm{kg}-\mathrm{CO}_{2} / \mathrm{MJ}\right)\end{array}$ & $\begin{array}{c}\mathrm{CO}_{2} \text { 排出量 } \\
\left(\mathrm{kg}-\mathrm{CO}_{2}\right)\end{array}$ & $\begin{array}{c}\text { 合計 } \\
\left(\mathrm{kg}-\mathrm{CO}_{2}\right)\end{array}$ \\
\hline $\mathrm{LPG}$ 使用量 & 271,006 & 0.0489 & 13,252 & \multirow{2}{*}{13,252} \\
\hline チップ熱量 & 0 & 0 & 0 & \\
\hline
\end{tabular}

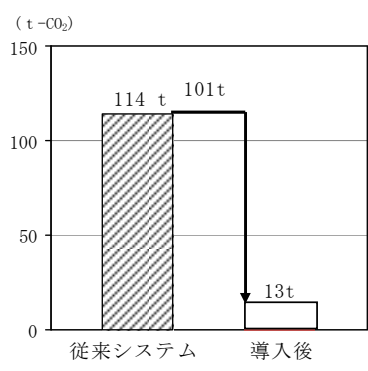

図 $12 \quad \mathrm{CO}_{2}$ 排出量変化

\section{4. $3 \mathrm{CO}_{2}$ 削減効果}

図 12 に $\mathrm{CO}_{2}$ 排出量変化を示す。WBCGS 導入後は従来システムと比 較して $109 \mathrm{t}-\mathrm{CO}_{2}$ 削減し、88.6\%削減したことになる。

\section{5. 総括}

-WBCGS の実績值として年間運転日数は 271 日、年間木材チップ使 用量は $390 \mathrm{t}$ で、1 日あたり木材チップ使用量は $1.44 \mathrm{t}$ あった。 ・WBCGS の年間総合効率は $62.9 \%$ 、発電効率は $10.6 \%$ 、熱回収効率は 52. 3\%であり、供給対象施設が年間消費エネルギーは、8, 374GJ/ 年でWGCGS によって生成されたエネルギーは、678GJ/年であった。 ・WBCGS 導入後は従来システムと比較して $109 \mathrm{t}-\mathrm{CO}_{2}$ 削減し、88.6\% 削減したことになる。

\section{謝辞}

本報を執筆するにあたり対象施設のクラブハウス、発電所、市役所 の方々に大変お世話になりました。記して感謝致します。

注

*1 参考文献 2)の pp. 46 に記載されている表 3.2.2-2 木質バイオマスの含水 率と低位発熱量 $(\mathrm{LHV})$ 設定值を使用して近似式を作成して含水率と燃料 使用量を乗じたもの。0.1433 $\mathrm{x}^{2}-42.125 \mathrm{x}+4800$ ( $\mathrm{X}$ は乾基準含水率)

\section{参考文献}

1) 杉崎聡, 高口洋人：東京都 23 区における街路樹 - 公園剪定枝発生量とその 有効利用に関する研究, 日本建築学会大会学術講演梗概集，pp. 737〜 738, 2008 年度

2) NEDO : バイオマスエネルギー導入ガイドブック，2005 年 9 月

3) NEDO : 新エネニッポン, 2007 年 3 月

4) みずほ総研株式会社 : バイオマエネルギー導入支援データベースの構築調 查 調查報告書, pp. 43〜 56，2007 年

5) 環境省：地球温暖化対策の推進に関する法律施行令、2007 年

[2009 年 10 月 20 日原稿受理 2010 年 3 月 6 日採用決定］ 